\title{
COMMON LAW AND COMMON SENSE
}

\author{
WILLIAM RENWICK RIDDELL \\ Supreme Court of Ontario
}

Early in the last century (I804), Mr. Smith, an eminent lawyer of Woodbury, Connecticut, in an eloquent and impressive argument before the Supreme Court of Errors ${ }^{2}$ indignantly disputed the proposition of Lord Mansfield stated in Corbett $v$. Poelnitz." "That as the times alter, new customs and new manners arise, and new exceptions and applications of the rules of law must be made." Inveighing against the sins of England, he exclaims:

"And, to be sure, manners have there led the law and law the manners, till all barriers are thrown down. And are we to go on in their tracks, not by degrees, but to take at once the last step which corruption has there introduced and bury in oblivion the principle that a feme covert has no separate existence?"

Counsel had never heard in Connecticut of exceptions to the marriage contract so that the wife need not lose her independence, or of relatives giving property to married women to their separate use; and he warmly insisted "that the generosity of our females has not allowed them to wish to keep their property from those to whom they have not refused their persons."

The Supreme Court of Errors, sitting at Hartford, to whom this typical argument was advanced, was composed of Jonathan Trumbull, the governor, ${ }^{s}$ Lieutenant Governor John Treadwell and ten assistants, all unknown to fame except Oliver Ellsworth, afterwards Chief Justice of the Supreme Court, of whom la RochefoucaultLiancourt, in that most delightful of all works of travel, his Voyage dans les Etats Unis d'Amérique, thus speaks (he calls him "Elleword," but that is a detail) :

"Les Américains qui passaient avec nous et qui presque tous étaient des jeunes gens n'avaient pas plus d’égard pour lui que pour

\footnotetext{
2 The substance of this article was contained in an address delivered before the graduating class of the Yale School of Law.

'Dibble v. Hutton (1804, Conn.) I Day, 22r, 224

(I785) I T. R. 8.

- One is irresistibly reminded of the address to a jury attributed to Erskineor sometimes to Scarlett, who though bright was not deep-read: "Gentlemen of the jury, the reputation of a cheesemonger in the city of London is like the bloom upon a peach. Breathe on it 1 -and it is gone for ever."

"Not the original Jonathan, Washington's "Brother Jonathan" who, beginning as a clergyman, ended up as a judge, but his son.

See I. W. Stuart, Life of Jonathan Trumbull, Serr. (Boston, 1859).
} 
le maître d'hôtel nègre, et cependant c'est, apres le Président le second, peut-être le premier personnage de l'Union."'B

That court stood by the old ways-steterunt super vias antiquas:

"the maxims of the ancient common law . . . are plain and simple; our state of manners and society do not require that they should be relaxed or qualified. The principles ... of the common law remain unimpaired."

When after 1783 some thousands of Americans passed from the new republic, chiefly from New York, Pennsylvania and New Jersey, but some from Connecticut and other parts of New England, across the international rivers into northern wilds, many of them victims of as gross a disregard of treaty as ever has been witnessed in historyat least until the present decade-they took with them that same common law which was the object of the reverence and devotion of Mr. Smith and the court he addressed in Connecticut.

The French-Canadian might wonder that they should think their property safer in the determination of tailors and shoemakers than in that of their judges-they were French and did not know any better;but the man of English descent, saturated with the common law could not endure any other. The French-Canadian law, the Coutume de Paris, had been reintroduced into all Canada by the Quebec Act of r774, greatly to the delight of the French-Canadian but much to the disgust and indignation of the English-speaking inhabitants. In the old province, the French largely predominated, but when the new settlers came into the upper part of the British territory, the Englishspeaking largely outnumbered the French there. The result might have been disastrous, since neither race could be satisfied with the law of the other; but the lesson of 1776 had been well learned. Britain, always sincerely anxious for the well-being and well-doing of her colonies-some school histories to the contrary notwithstanding-and she did make mistakes-had thoroughly learned that the colonies and the colonists must be and do well in their own way and not necessarily in hers; that the way to make colonists contented is to let them alone, and that in most instances they know infinitely better what is best for them than any statesman three thousand miles across the sea, however enlightened and however benevolent.

Accordingly the wise scheme was devised of making two provinces, one in most part populated by the French-Canadians, the other in most part populated by the newcomers, Americans. The Con-

\footnotetext{
- Voyage dans les Etats Unis d'Amérique fait en 1795, 1796 et 1797 ; par la Rochefoucault-Liancourt á Paris lan VII de la Republique, tome Quatrième, 2, 3. "To whom our American fellow-passengers, most of them young, showed no more respect than to the negro waiter, and yet he is after the President, the second, perhaps the first, personage in the Union."
} 
stitutional or Canada Act of I79I formed two provinces, Upper Canada and Lower Canada, and gave to each full power of legislation, civil and criminal. In 1792, when the parliaments met in the two provinces, while the French province, Lower Canada, retained its law, the upper province by its very first act introduced the law of England, and by its second the full jury system. ${ }^{7}$ So strongly devoted to the common law was Upper Canada that she went for nearly half a century without a court of chancery-her first court of chancery not appearing till 1837 . What was the cause of this intense attachment to the common law of England shared in by all of English stock-indeed, by all who spoke English, for the Scot, having come to a common-law country, soon forgets his Scottish law, based as it is on the civil law of Rome, and cleaves to the English law?

For Upper Canada we may say that she was a British possession formed into a state by an Act of British Parliament; but Connecticut formed her own constitution, and

"so far as its provisions are concerned the King and Parliament ... might as well have been non-existent. It is made... on the authority of the people ... its objects are to establish an orderly and decent Government ... and for these purposes its authors do ... associate and conjoin themselves to be as one Public State or Commonwealth."8

Is not the real reason to be found in the belief that the common law is the perfection of human reason-in a word, that the common law is common sense? What we call "common sense" is not the old metaphysical common sense, nor is it the sentiment which might be conceived to flow from lofty and altruistic philosophy; but it consists in the application of the rules of justice and honesty to the things of this work-a-day world, so full of anomalies and of fallible, imperfect, human beings.

A well-known English judge, watching village children drawing up rules for their cricket team for the year, said they were showing him how the common law of England was made. I venture to think that this view is not quite correct. The common law was no set of rules purposely drawn up for the governance of the community but rather a set of customs which evolved into form in the course of years. Now and then, indeed, the sovereign power intervened to modify the old rule or prescribe others; but in most cases where the judge was called on to give a decision he was not like the umpire at cricket

This is more fully explained in articles on the Early Courts of the Province (Ontario), Can. Law Times (Igr5) 879, 964.

See The Genesis of a New England State (Connecticut), by Alexander Johnston, A.M., Johns Hopkins University Studies, No. XI, Baltimore (Sept. I883) 14, I5. The language has been here slightly modified and the archaic spelling modernized. 
or baseball, sent to his body. of formal and fixed rules to find out what should govern and to decide according to the rule prescribed; he was rather like the friendly arbitrator deciding according to what he considered the requirements of decent neighborhood, that is "the customs of the country"-Sittlichkeit, if you will. Every time he made a decision, he made the custom more definite. He did not, indeed, affect to lay down any new rule or to govern himself by any but the existing sense of the community-that is, what was just and right in the particular case, bearing in mind the customs which were followed and which fixed rights and duties, more or less indefinitely indeed, but nevertheless fixed them. But every time, he used his own sense of what was just and right in the particular case. Every art tends to become a science, practice inevitably demands theory, and when law came to be written it was rather deductive than inductive: the judgments were examined, and from them the general rule was deduced. The real law is always the state of the decisions for the time being, whatever may be the state of the rules supposed to be binding.

"One-third of a judge is a common juror if you get beneath the ermine," says Lord Bramwell, and the other two-thirds may not be far different A judge is necessarily the creature of his times. In our system the judge comes from the bar; he is not educated as a judge, but as a lawyer, who handles matters of everyday life, and is in close touch with the people. The common sense of the judge was not far away from the common sense of the mass of the peopleand the dicta of the judge recommended themselves to the people because they were much the same as they would themselves have uttered had they been articulate.

So long as the law was unwritten, there was no difficulty in the evolution of legal precept keeping pace with social and international evolution. But litera scripta manet rigescitque: once the decision is written, it cannot be overlooked, nay, it must be followed, and law necessarily becomes fixed, unyielding, in a sense arbitrary.

Common sense is not the same in all ages. In the times of Matthew Hale, common sense told everyone that there were such things as witches." Was one blasphemously to asşert that the Almighty did not know what he was talking about when he said, "Thou shalt not suffer a witch to live?" Were there not many cases in which old women had confessed their sin and even boasted of it? What other explanation could be given of the abnormal phenomena-they called them "wonders"-so often witnessed than that they were produced by the power of Satan? Not only in the mother country but on this side of the Atlantic, not only at Suffolk, England, but at Hartford,

-Cf. Leckie, History of Rationalism. 
Connecticut, unfortunate beings, more than half convinced of their own guilt, suffered the extremity of the law for a crime which our common sense tells us does not exist. The conception of witchcraft is to us hardly consistent with sanity. Was the whole nation then insane?-for no doubt there is much truth in Butler's contention that nations may become insane, like individuals. It may indeed be that the present age is witnessing such a phenomenon. Insane? Not at all, but wholly sane, considering their light and the available evidence.

So in the case of the woman. The first woman was made subject to the first man; in the first reported criminal trial the judge pronounced the sentence, "He shall rule over thee"-and of course the subsequent women must be subject to the subsequent men. Then, too, in the state of society when the common-law rules were in the making, the woman could not be of much avail in making property or in keeping it-working or fighting to procure or to protect. She was weak compared with the man, and craft had not yet come into its own. It "stood to reason," then, that every woman should have a man for a master, and that she should not be trusted with property which she did not make and which she could not keep. It was much that she was allowed an immortal soul of her own; all else was properly and naturally her husband's. If some one beat her or otherwise injured her, the husband should sue, for he was the master and he was the injured party.

It is difficult for us to breathe in the intellectual atmosphere in which such were the real views of the community; but that community was wholly sane and their views were common sense. That common sense, however, passed away with a speed more or less rapid at various periods; and justice demanded the recognition of woman's rights in her own property.

Equity had of course done something, but not enough; the common law riguit, was inflexible and unbending; and the legislature had to interfere. Accordingly, in some places sooner, in others later, the married woman was declared to be a human being with the ordinary rights of property as a human being. This terrible change in the law, the very thought of which so shocked the sages a century ago, does not seem to have destroyed society. God is still "in His.heaven and all's right with the world."

In a late volume of the Connecticut Reports I find it solemnly laid down that a woman may sue her husband for an assault and battery committed on her person. ${ }^{10}$ Shades of Coke and Blackstone! Some fine morning the community may wake up and actually find that a married woman may be intrusted with a voice in selecting those who are to make laws for her, with no greater danger to the state than

Brown v. Brown (1914) 88 Conn. 42. 
that caused by giving the vote to the emancipated negro or the immigrant not far removed in time or in intelligence from serfdom.

Whether this change will be welcomed or not must depend on the state of mind of the community, whether more or less intelligent, less or more reasonable-I decline to express any opinion whether it is the less or the greater amount of intelligence and reason which will determine a change.

Now to another bit of history. As I write these lines, I have before me a little volume, ${ }^{11}$ written ninety years ago by the Reverend Ammi Rogers, a minister of the Episcopal church, who seems to have had rather a hard time of it in his day. He barely escaped imprisonment in the Newgate of Connecticut at Simsbury (now East Granby), and was imprisoned for $73^{\mathrm{I}}$ days in the Norwich jail-just for being a Republican, he says. Quis talia fando temperet a lacrymis? There was indeed a trifle of a conviction for crime-but we are assured that the charge was false (which indeed is likely enough), and would not have been prosecuted but that he opposed the Presbyterian or Federal party-credat Judaeus Appella. He says:

"In Connecticut every settled congregational Presbyterian minister can send his collector and take any man's horse from under him, or his oxen or cows or hogs, or any property which he possesses, unless he has signed of ${ }^{12}$ and can sell it at the post without suing him or granting him a hearing. I have known them take even a man's Bible and sell it at the post to pay the minister's tax. I have known Episcopalians, Baptists and others actually locked up and confined in a filthy disgraceful jail in Connecticut merely because they would not or could not in conscience pay their money to support that which they did not believe to be true."

The common law-whether assisted or not by royal edict or legislation is of little importance-early settled that "an honourable and

"Memoirs / of the / Rev. Ammi Rogers, A. M., / a Clergyman of the Episcopal Church, educated at / Yale College in Connecticut, ordained in Trinity / Church in the City of New York / Persecuted in the State of Connecticut on Account / of Religion and Politics for almost Twenty Years / . . . Composed, Compiled and Written by the said / Ammi Rogers / Late Rector of St. Peter's Church in Hebron, Tolland Co., Conn. Etc. / . . . Second Edition / Schenectady Printed by G. Ritchie, Jun. / 1826, $12 \mathrm{mo}, 272 \mathrm{pp}$. The quotation is from p. 5 I.

${ }^{12}$ A delicate touch-fraudulent conveyances have been in use ever since there have been conveyances: but just to think of anyone trying in this way to beat the parson 1

My friend, Governor Baldwin, informs me that I have quite misapprehended the meaning of "signed off" in the connection. He says that "signing off" was the filing with the proper authorities of a paper certifying that the person belonged to some other religious body, and he gives me an instance of one gentleman's filing a certificate something like the following:- "T, John Smith, hereby certify that I have ceased to be a Christian and have joined the Episcopal Church." 
competent maintenance for the ministers of the gospeI was jure divino," that those who separated from the world for the sake of the rest of mankind had "a right to be furnished with the necessaries, conveniences and moderate enjoyments of life at the expense of those for whose benefit they forego the usual means of providing them."13

One has only to read Gladstone's Church and State to see how entirely reasonable such a state of the law is-provided he belongs to the favored church. The Dissenter, whether Presbyterian as in England or Episcopalian as in Scotland and old Connecticut, can never be persuaded that the logic is sound; but then he is a dissenter.

The common sense of the people then in Connecticut, as now in certain other parts of the globe usually looked upon as civilized, considered that the value of true religion was such that all legitimate means should be used to spread it, including support of its teachers by the community from public funds; that all should contribute to these funds and this support-the only question open being, "What is the true Religion?" Connecticut settled that early and conclusively; it was the particular brand offered by the Congregational Presbyterian.

In Upper Canada we had not such an easy task. First, the Church of England, or Episcopalian, claimed a monopoly of state support, derived from the sale of land, the "Clergy Reserves"; then the Established Church of Scotland claimed a share and had its claim allowed. Other religious bodies asserted equal rights with these, but Non est bonum sumere panem filiorum et mittere canibus, and the favored churches grudged even that Catelli edunt de micis quae cadunt de mensa dominorum suorum. ${ }^{14}$ Our people at last grew tired of the jangle, and took away the land-or such of it as was left-from the churches altogether, and applied it to education. We have a brutally direct way of doing things in my dehocratic country, and have no trouble over constitutional limitations. ${ }^{15}$

Our common sense changed; so in Connecticut the common sense of the people changed, and now one would be looked upon as not far from a lunatic who should propose a return to the old practice. I do not think that even the "settled congregational Presbyterian minister" regrets the change or would desire to take a man's horse from under him even if he had not "signed off"-not to mention the "man's Bible."

About the year I802, one Joel Goodyear sued the administrators

12 Tomlins, Law Dictionary, sub voc., "Tythes" I.

"Vulgate version, Matt. XV. 26-27.

1s "The prohibition 'Thou shalt not steal' has no legal force upon the sovereign body ... We have no such restriction upon the power of the legislature as is found in some states." Florence Mining Co. v. Cobalt Lake Mining Co. (I908) I8 ONT. L. Rep. 275, 279, per Riddell, J., affirmed in the Court of Appeal and the Judicial Committee of the Privy Council 
of Joel Bradley in "an action of book debt," and at the trial in the Superior Court of Connecticut, ${ }^{10}$ he was allowed to give his own evidence to establish that he had sent the decedent $\$ 100$ in cash by his negro to apply on his promissory note. This would never do. The defendants appealed, and by two eminent counsel urged that the "principle adopted by the Superior Court would enable any man to swear away his own note of hand." Counsel on the other side were not so bold as to contend that a party could be allowed to give evidence in his own behalf in an ordinary case, but they argued that it was different in an action "where the plaintiff charged the defendant on book." The Supreme Court of Errors was adamant. "The plaintiff cannot in any form of action avail himself of his own testimony"notwithstanding a previous adjudication by the court, of which "the consequences which have followed probably were not then foreseen."

At the common law, common sense taught that anyone allowed to give evidence on his own behalf would perjure himself. As Bentham puts it, "every defendant is par etat, by his station in the cause, a liar, a man who if suffered to speak would be sure to speak false"-in other words, a litigant is a liar ex officio. ${ }^{17}$ Accordingly, from this presumed want of integrity, all parties are excluded from giving evidence.

Once this was sound common sense, wherever the common law prevailed; but the common sense has changed almost everywhere. Connecticut is considered by some to have led the van when in 1849 she removed all disqualification on the ground of interest, ${ }^{18}$ and not for two years afterwards did England take the same step for all courts, though she had launched the experiment in certain courts in $1846 .{ }^{19}$

But I claim priority for my province. As early as $1792^{20}$ in erecting courts of requests for the easy and speedy recovery of small debts, the parliament of Upper Canada expressly provided that it should be lawful for the justices "to administer an Oath to the Plaintiff or Defendant as well as to such Witness or Witnesses as shall be produced by each Party." It is true that we did not introduce this into the superior courts till I856; but then we are not a logical people.

For more than half a century in most jurisdictions the theory that a party must not be allowed to give evidence on his own behalf has been effete, and no one but a fool would suggest its reinstatementthat is, he would be a fool only if, in making such a suggestion, he had in contemplation a civil action.

\footnotetext{
1s Bradley v. Goodyear (1803, Conn.) I Day, 104, 105.

${ }^{17}$ I once heard a college president say "a College President is a liar ex offic : 0 " - he proved his own status-for if he told the truth he was a liar.

"Wigmore, Evidence (1904) par. 577, note 4

10 Boyle v. Rothschild (1908) I6 ONT. L. REP. 426.

* See Statutes of Upper Canada, I792, 32 Geo. III, ch. 6, s. 3.
} 
In many jurisdictions one charged with a crime is not allowed to give evidence on his own behalf; the person who must know most about the facts has his mouth closed. Why? Because he is apt to disregard the truth and may perjure himself?-But that fear we disregard in civil actions. Because he may injure his own case?-Why shouldn't he, if he wants to? In some jurisdictions the accused is permitted, but cannot be compelled to give evidence on his trial. That is our law in Canada.

"This restriction is part of, or intimately connected with the traditional law that no one should be compelled to condemn himself. There was reason in such a rule when the criminal was not uncommonly one who had offended the powers that were, and too often it was to be feared that the self-condemnation was brought about by torture. But now the criminal is always the enemy of society, of the people and not of the king or government. No one desires the destruction of the accused because he is he, and irrespective of whether he has committed a real crime. The whole concern of the prosecution is (or should be) to investigate whether the accused has committed an offence against the people; not only does the law not desire the punishment of an innocent man, it does not desire the punishment of a man who cannot be proved guilty."21

Not being a prophet or the son of a prophet, I do not venture to predict that at some time in all common-law countries the accused will have just the same rights as a defendant in a civil suit, nor do I try to bring on that time anywhere. Every people has the government it deserves-leaving aside cases of physical force,-so every people should have the law with which it is satisfied.

If there is one matter more than another which excites the interest of an Ontario lawyer in the courts of some of the states of the Union (I except of course the enormous length of time taken in trials), it is the devotion to the jury system. This is a cardinal characteristic of trials at the common law, and most common-law countries insist upon its retention. With us, it is the exception that a civil case is tried by a jury-and indeed, the vast majority of criminal cases are also disposed of by a judge. I shall speak chiefly of the civil side.

Looking at the matter from an a priori point of view, there is no magic in a jury trial; there is nothing at all inherently necessary to an English-speaking community in the "institution" of the jury. Take, for example, the history of Connecticut. The wealthy and somewhat aristocratic body of immigrants who arrived on this continent from England in 1637 , and, resisting the inducements held out at Boston to settle in Massachusetts, came the following year and founded a colony of their own, New Haven, differed in one respect at least from the poorer immigrants who a year or two before had

"The quotation is from an address delivered before the Wisconsin Bar Association at Green Bay, Wisc., June, rgr4 
come from Massachusetts and settled in and near Hartford-the "Connecticut" Colony. Hartford or "Connecticut" provided for trial by jury; New Haven did not; and there is no record or tradition indicating that the New Haven courts were any less effective in doing justice than those in the colony up the river or in its Say and Sele purchase at Saybrook. That the jury system conquered in Connecticut (as elsewhere), was one more of the indignities to which this aristocratic but unhappy settlement was forced to submit by way of penance for its slackness in hunting down the regicides Goffe and Whalley and its want of promptness in recognizing that the King had come to his own again.

For long it was bad law, and for longer, bad form, for a judge, trying a case with a jury, to express an opinion on the evidenceexcept indeed in a government prosecution; the unfortunate. who set himself up against the constituted authorities had of course no rights. In some jurisdictions the law still is that the judge must not express his opinion on facts; the common sense of such communities tells them that if you have a jury trial you should have a trial by jury; the judge is there simply to act as an umpire-."to see fair"-and declare the law.

Judges do not like to be thus limited in-their activities-crede experto-and in some places sooner, in some places later, they began to express opinions. Even as late as the middle of the last century we are told by a celebrated English solicitor:

"In fact, in trials by jury (and no causes were or could be tried without a jury) the presiding judge was supposed to be impartialor rather, to express no opinion, but in summing up merely to explain the law and read or refer to the evidence given on the one side and the other, without intimating his own view or openly endeavoring to influence the jury as to the verdict they should give. But this kind of impartiality was dying out."22

So in Connecticut, at least as early as $185 \mathrm{I}$, it was laid down as clear law that the trial judge had the right to give in his charge a clear expression of his own opinion, so long as he made it plain that

Jottings of an old / Solicitor / By Sir John Hallams / London / John Murray, Albemarle Street $W . /$ 1906."

He says

"it became common for counsel to impress on jurors that it was for them to decide and that they ought not to be influenced by the Judge. I well remember a trial at Guildhall before Chief Justice Jervis . . in which Serjeant Wilkins made, as was his wont, a very excited speech to the jury in replying for the plaintiff, and concluded by saying 'I tremble for liberty, I tremble for justice, I tremble for my country, when I find a Judge ignoring his position of impartiality, 11surping the functions of a jury, the safeguards of the liberties of Englishmen and endeavouring to deprive my client of that unbiassed verdict of a jury of his country to which he is entitled." 
he did not intend to "direct or control" the jury. From that, the state has never departed. In my own province the same law has been followed from time out of mind.

That practice has recommended itself to the common sense of some peoples; but others have not yet been infected with the virus, and still think that a jury trial is a jury trial and the litigant has the right to the opinion of a jury uninfuenced by the umpire. That the umpire may promptly set aside a finding which he thinks not in accordance with the evidence is a detail; there is, anyway, the chance of another jury, and another; and courts sometimes get tired of setting aside verdicts. Logical consistency is on the side of this practice; but since when has an English-speaking people cared for consistency? What works well is with them all right, even if it is not logical. A Frenchman will fight half a dozen duels before breakfast for a principle; but the practical "Anglo-Saxon"24 cares only for a practice; theory is a beautiful thing, but we want something that will do good work in this work-a-day world.

Not to worry about logic and consistency, is there any good reason why the judge, a trained observer accustomed to hear and weigh evidence, better educated than most jurors and presumably of higher intelligence and capacity (the presumption is not juris et de jure), should not help the jury, not only by reading to them the evidence, but also by giving fully and fairly his own views of its weight and effect? Counsel do that from one point of view and the other; why not the judge from an impartial point of view? The answer of the common sense of the community will determine the course of the courts; for every community has the law it wants.

In most common-law countries we have not got to the standpoint of the French-Canadian a century and a half ago; tailors and shoemakers are still preferred. to judges in determining the rights of litigants. True, in a very large class of cases, a chancellor or other equity judge may sit and determine not only law but also fact. Why should the same thing not be done in other cases? The distinction between legal and equitable issues is of course historical; there is no difference in ethics or morals; and (leaving aside history) it is hard to see why a judge who can satisfactorily decide a question of fact

"First Baptist Church and Congregation in Stamford v. Rowe (185I) 21 Conn. 160,166 . Stamford, now I understand a most decorous place, was in early times the most unmanageable of the towns of Connecticut. Colonized from Wethersfield, one of the three Connecticut towns, bought by New Haven in 1640 , it became and long remained a thorn in the side of the grandees of New Haven.

${ }^{2} I$ use the wholly incorrect and somewhat misleading terminology for want of a better. I mean those who speak English and are either of English descent or have adopted the English conception of legal and political right, law and government. 
in a proceeding on a mortgage or a trust should not do equally well in a proceeding on a contract or a trespass. Why the practice should be followed of a judge directing a jury to find so-and-so instead of his trying the issue himself and doing his own finding, is well deserving of careful consideration. There may be many cases of fact which a judge prefers that a jury should determine; and one can see no objection to that course in such cases-generally very simple and depending on the relative credibility of witnesses. But in most cases, is not the judge more likely to be right than the "tailors and shoemakers"?

In our Untario practice no one is entitled as of right to a trial by jury excepting in cases of libel and the like. If anyone desires a jury trial, he files a notice for a jury, but the trial judge determines whether the case shall be tried by a jury or not; and even if neither party has filed a jury notice the judge may order a jury to be called. An enormous amount of time is saved by dispensing with a jury. There are no opening addresses and the final addresses are cut short; objections to evidence lose much of their importance, oratory is at a discount and lucid sensible argument at a premium. The common sense of our people says that is an improvement. That of other people will depend upon what they wish the courts to be and what they think of their judges.

A people which really thinks the court a place of amusement, a stage for the display of oratory, and a lawsuit an interesting game to be won by technical skill and ability to take the measure of a jury's foot, or which does not trust in the integrity and capacity of its judges, will of course insist on the traditional method of trial; but if the judges are trusted both as to their ability and as to their honesty, if a lawsuit is conceived of as a real means of doing real justice and of giving every man his own, there surely can be little question what course will, at least in most cases, be adopted. Even if a jury be insisted upon-and in criminal cases few English-speaking communities have abolished the jury in the most serious cases, even on consent-the time taken in securing a jury is sometimes a public scandal.

I was recently told by a brother judge that it had taken him an hour to empanel a jury to try a certain criminal case which excited much public interest in Toronto. Until that day I had never heard of it ever taking more than half an hour to procure a jury in my province, and my experience is neither small nor unique. When we Canadians hear of it taking days, weeks or even months to swear a jury, we involuntarily clap our hands on our pockets; we know we could not afford any such luxury, and marvel at any others being able to stand it. ${ }^{25}$ Whether the common sense of such other com-

\footnotetext{
* I have more than once told the story of my going as a trial judge to a
} Canadian city along the same line of rail that would have landed me in a few 
munities will abolish what to Canadians looks so absurd, will, as in all such matters, depend on the view taken of the true function and object of the courts.

Passing from this subject, I would say a word or two as to "practice." If courts are to be held as a means whereby the citizen may vindicate his rights, much attention must be paid to the methods through which this object is to be attained. It is inevitable that general rules should be laid down for the conduct of litigation, and it is natural that these rules should tend to become rather an end in themselves than a means toward an end.

The old law of procedure was like everything primeval-a matter of custom, formal; it gave much weight to set words, set phrases, fixed methods. Everything in a primeval community partakes of the nature of a religion, a magic; formulae are sacred; to depart from them fatal; this way is right, all else wrong. But as life becomes wider, more complex, the value of mere words goes below par, and facts press their claim. A slip in practice is thought to be only a slip and not a crime or a fault of such gravity as to deprive him who made it, or his client, of his rights. It is no doubt a very nice thing to have a perfect record without blot or interlineation or defect; but it is of much more importance that a litigant should have his rights.

And now, in all communities really civilized, a technical court which haeret in cortice is considered a scandal; errors made by a lawyer in reducing to writing his client's case are punished, if necessary, by costs, but are not allowed to interfere with justice according to the very right of the matter, according to the facts established and not according to the language in which a writer has expressed a claim: Once a community has advanced to the stage in which its common sense teaches that rights depend upon facts and not upon statements, upon facts and not upon technical skill in draftsmanship and acumen in taking advantage of rules, it will insist that the courts at every stage shall be independent of form, shall amend where necessary, shall not be shackled by antiquated or even modern rules which would prevent full justice being done to all.

I have often quoted the remark of the late Goldwin Smith: "It is as reasonable to expect the tiger to abolish the jungle as the lawyer to seform legal procedure." Even a professor of history may not be wholly cognizant of the history of legal procedure; and certainly that statement shows lamentable ignorance of the facts, historical and otherwise, of legal reform. The tiger has never abolished the jungle, but the law has always been reformed by the lawyer. Whether the law is considered as adjective or substantive, that has always been so, both in England and on this continent. It must continue to be so, or

hours more in an American city. In this city a court began to empanel a jury in a murder case upon the same day on which I opened my court. I had tried four criminal cases and seven civil cases and was home in Toronto before my American brother had six jurymen in his murder case. 
reform will stop; for the leadership of the lawyer in all such matters is firmly established. He knows the defects, and can best devise the remedy. No call of public duty can be more insistent than the call to make and keep the courts as useful as possible. It cannot be denied that in some jurisdictions the courts do not in all cases do all that is expected of them; that efficiency methods seem not adapted to them; that they fail in doing justice in many instances; that, in more, the cost is utterly disproportionate to the good effected; that the practice is unwieldy and offers to the astute, means of escaping the just result of his acts.

Sometimes the hands of the court are tied. A legislature which allows the doctor to practise in his own way ( $s u b$ modo) prevents the lawyer from doing the same, and will not even permit the expert lawyer of the judiciary to lay down the rules. Why the court should not, within reason, have the power to prescribe its own practice I cannot conceive, unless it be that the judges are not trusted or are not believed to know more about the needs of their court than the legislator.

Defects there must be in everything human-errare humanum estdefects in the judge, defects in the practice, defects in the practitioner; but these may be minimized. Where the judge is elected, it is the lawyer who decides who shall be the candidate. An honest and capable bar will not tolerate any but an honest and a capable bench. Honest and capable judges will see to it that a reasonable practice is prescribed if they have that power, and if they have no power to prescribe or alter, they will see to it that the existing practice is reasonably interpreted. But yet I must qualify these statements a little"nature is subdued to what it works in, like the dyer's hand." A judge, however honest and however capable, is prone to stand by the old ways-stare super vias antiquas-and to change as little as possible. It is hard for anyone to learn that the art on which he has spent many a diligent hour is worse than useless. ${ }^{26}$ Moreover, a judge is necessarily conservative ex officio. In not a few cases, honest and capable judges have by that very conservatism rendered, if not nugatory, at least less useful, changes which have been prescribed. The poet sings:

"For forms of government let fools contest,

"That which is best administered is best."

He does not, I presume, expect his readers to accept that maxim literally; at all events they will not. An American could not become monarchist or a Canadian, democratic as he is, become republican. Still, there is much truth in it. So, too, in the administration of the

\footnotetext{
2 The lament of the bankruptcy lawyer is well known-on the repeal of a Bankruptcy Act he wailed, "Congress has abolished all I ever knew."
} 
law, there is no little importance to be attached to the idiosyncracies of the judge. Some can make an almost villainous practice quite tolerable; others a tolerable practice almost villainous-and all equally honest and capable. All desire to do justice according to law, but some lay the emphasis on law, as others on justice. Therefore I add, it is not enough that a judge shall be learned, honest and capable; he must have a passion for justice irrespective of formality.

It is for the bar to see to it that such judges are selected and to support them in all reasonable efforts towards reai justice. The lawyer is a member of a liberal and a learned profession. He must indeed do all for his client which the existing practice permits and the rules of honor do not prohibit; but nevertheless he must remember that he is a citizen of a free state, with an interest deep and abiding in its advancement; he must never forget that on this continent the lawyer is the leader in the thought of the people, that the common sense of the lawyer tends ever to become the common sense of the community. He should be in advance of his fellows; he must enlighten and attract; as he leads, the rest will soon follow. 